\title{
Early and Later Phonological and Language Development of Children with Cleft Palate
}

\author{
Minkyeong $\mathrm{Pi}^{\mathrm{a}}$, Seunghee $\mathrm{Ha}^{\mathrm{b}}$ \\ ${ }^{a}$ Graduate Program in Speech Language Pathology, Hallym University, Chuncheon, Korea \\ ${ }^{b}$ Division of Speech Pathology and Audiology, Audiology and Speech Pathology Research Institute, Hallym University, Chuncheon, Korea
}

\author{
Correspondence: Seunghee $\mathrm{Ha}, \mathrm{PhD}$ \\ Division of Speech Pathology and Audiology, \\ Audiology and Speech Pathology Research \\ Institute, Hallym University, 1 Hallimdaehak-gil, \\ Chuncheon 24252, Korea \\ Tel: $+82-33-248-2215$ \\ Fax: +82-33-256-3420 \\ E-mail: shha@hallym.ac.kr
}

Received: April 10, 2018

Revised: May 21, 2018

Accepted: May 21, 2018

This study was supported by Hallym University Research Fund (No. HRF-201804-010)

\begin{abstract}
Objectives: The purpose of this study was to examine phonological and language outcomes of children with cleft palate (CP) at 36 months of age, who present differing levels of early language skills which were identified at 24 months of age by parent reports. Methods: The participants were 7 children with CP who presented delayed expressive language (DEL) group, 6 children with CP who presented normal language development (NLD) group, and 7 typically developing children (TD). Fifty utterances were collected from these 20 children and analyzed using phonological measures (PMLU, PWP, PWC, PCC, consonant inventories) and language measures (NDW, NTW, MLUw, MLUm). Results: DEL children with CP scored significantly lower on phonological measures when compared with TD; while the NLD children with CP showed no significant difference with the TD. No significant differences between the three groups were found in the language measures; however, half of DEL children with CP did not reach the language level of TD. Conclusion: These findings suggest that DEL children with $\mathrm{CP}$ have weaker later phonological skills in comparison to both TD and NLD children with CP. However, in terms of language skills, they appear to catch up to the other groups. These results suggest that early intervention with children with CP who are identified as high risk through parent reports at 24 months should aid on phonological development.
\end{abstract}

Keywords: Cleft palate, Expressive language delay, Phonological development, Language development, Early intervention
구개열 아동은 생후부터 구개 재건 시까지 지속되는 구강 및 연 인두의 구조적 결함으로 인해 생애 초기 말·언어 발달에서 어려움 을 보인다(Chapman, 1991; Chapman, Hardin-Jones, Schulte, \& Halter, 2001; Ha, 2014; Kuehn \& Moller, 2000; Park \& Ha, 2016; Pi $\& \mathrm{Ha}, 2017)$. 이같은 어려움은 구개 수술 이후에도 말소리 발달 지 연, 보상조음 산출, 수용언어와 표현언어 발달 지연, 문해 어려움 등 으로 이어진다고 알려져 있다(Kim, Kim, \& Kim, 2002; PetersonFalzone, Trost-Cardamone, Karnell, \& Hardin-Jones, 2006).

시기별로 구개열 아동의 말·언어 발달에 대해 일반 아동과 비교 한 다수의 연구가 있다. 수술 이전기 구개열 아동은 일반 아동에 비 해 성문음이 포함된 발성을 빈번하게 산출하였으며 음절성 발성에 서 비자음의 산출비율이 높았고 구강 압력이 필요한 자음들의 산 출비율은 낮았다(Chapman, 1991; Chapman et al., 2001; Grunwell
\& Russell, 1987; Lohmander-Agerskov, Söderpalm, Friede, Persson, \& Lilja, 1994; Willadsen \& Albrechtsen, 2006).

수술 이후 구개열 아동은 2 세 이후에도 음운능력이 불안정하고 다양하게 나타나, 또래 아동에 비해 말소리 발달이 미숙하거나 특 정 말소리를 선호하는 모습이 지속되었다(Harding \& Grunwell, 1996). 음운능력 이외의 어휘능력이나 평균발화길이(mean length of utterance, MLU) 등 언어 측정치들도 일반 아동에 비해 유의하 게 낮은 것으로 나타났다(Broen, Devers, Doyle, Prouty, \& Moller, 1998; Jocelyn, Penko, \& Rode, 1996; Scherer \& D’Antonio, 1995). 또한 일반 아동에게서는 흔히 관찰되지 않는 구개열 아동 특유의 말소리 오류패턴도 관찰되었다. 이에 대해 자세히 살펴보면 후방화 는 3 세경의 일반 아동에게서 나타나는 비전형적인 오류패턴이지만 구개열 아동에게서는 보편적으로 나타나는 오류패턴이다(Chapman 
\& Hardin, 1992; Chapman, 1993; Harding \& Grunwell, 1996). 또 한 비자음화(nasal realization; /ㅂ/가 /미로 실현되는 것)나 비음 동화(nasal assimilation; 비자음이 있는 단어에서 비자음이 아닌 다른 자음도 비자음으로 동화되는 것)도 구개열 아동들에게서 주 로 관찰되는 오류패턴이었다(Chapman \& Hardin, 1992; Morris \& Ozanne, 2003). 구개열 아동과 일반 아동 사이에 차이를 보이는 음 운오류패턴 비율은 5 세경에 이르러서야 감소한다는 보고가 있다 (Chapman, 1993).

구개열 아동의 언어 수행력 부분은 다수 연구자에게서 의견이 분분하다. 일부 연구에서는 학령전기 및 초등 저학년인 구개열 아 동과 일반 아동이 어휘기술(Chapman, 2011; Collett, Leroux, \& Speltz, 2010)과 문법기술(Chapman, 2011)에서 유의미한 차이가 나 타나지는 않았다고 보고되었으나, 또 다른 연구에서는 구개열 아동 중 상당수가 표준화된 평가도구를 이용한 문법과 어휘 과제에서 취약한 수행력을 보인다고 보고되었다(Young, Purcell, \& Ballard, 2010).

각 시기별 비교 이외에도 수술 이전기 구개열 아동의 초기 발성 이 이후 말.언어 발달과 밀접한 관계가 있다는 연구결과들도 있다 (Chapman, Hardin-Jones, \& Halter, 2003; Lohmander \& Persson, 2008). 구개열 아동이 수술 이후 정상 구강구조를 갖춤에도 일반 아동에 비해 자음이 포함된 음절성 발성의 발달이 늦고 산출비율 이 낮다고 보고되었다(Ha, 2018; Kim \& Ha, 2013; Park \& Ha, 2016). 또한 9 개월의 음절 유형수가 24 개월의 자음목록과 어휘수와 상관 이 있다고 한다(Park \& Ha, 2016). 그밖에도 9개월의 음절성 발성비 율이 39 개월의 말소리 산출과 유의한 상관이 있는 것으로 나타났 다(Chapman, 2004).

수술 직후의 구개열 아동의 음운 발달은 이후 시기의 말.언어 발 달과 관련이 있다고 한다. Chapman 등(2003)의 연구에서는 수술 직후 13 개월의 진자음 및 파열음 산출이 21 개월의 의미 있는 발화 에서 나타난 발화길이 및 어휘수와 유의한 상관관계가 있다고 보 고하였다. 국내 연구에서도 수술 이후 15 개월 구개열 아동의 음절 유형수와 음절성 발성 산출비율, 종성 자음수는 24 개월의 표현어 휘와 유의한 상관이 있고, 15 개월경 초성 자음수는 24 개월의 조음 정확성과 상관이 있었다(Park \& Ha, 2016).

다수 연구는 구개 수술 이후 3 개월 내에 구강 파열음이 산출되지 않은 구개열 아동을 조기 중재 대상자에 포함해야 한다고 제안한 다(Hardin-Jones, Chapman, \& Scherer, 2006; Peterson-Falzone et al., 2006). 또한 Hardin-Jones와 Chapman (2008)에 따르면, 24개 월 이전에 위험군으로 선별되어 조기 중재에 개입된 구개열 아동 은, 그렇지 않은 구개열 아동에 비해 10 개월 후 자음정확도뿐 아니
라 부모 보고에 의한 표현어휘수도 유의하게 증가하였다고 한다. 국 내연구에서도 12-30개월 구개열 아동을 대상으로 부모 교육을 활 용한 조기 언어 중재를 실시한 결과, SELSI 등가연령, K M-B CDI 표현어휘수, 명료한 구어 사용의 빈도, 자음목록수, 파열음과 유음 의 산출, 음절구조 다양도와 같은 다양한 말·언어 지표에서 유의한 향상을 보였다고 한다( $\mathrm{Ha}, 2011)$. 즉, 2 세 전후의 어린 구개열 아동 을 조기 선별하고 조기 중재를 제공하는 것은 매우 중요하다.

현재까지 나타난 대부분의 선행연구는 구개열 아동이 일반 아동 에 비해 말-언어 발달이 지연됨을 보고하고 있다. 이는 구개열 아동 을 동질적인 집단으로 묶어서 살펴본 것이다. 하지만 구개열 아동 은 수술 시기, 빈번한 중이염 유무, 수술 이후 연인두 구조와 기능, 표현언어능력의 차이 등에 따라 수행력이 달라질 수 있다. 따라서 구개열 아동의 개별적인 특징과 수행력을 고려해서 아동에 따라 중 재 시작 시기를 타당하게 결정해야 하고, 중재 방향에 대한 가이드 라인을 충분히 제공해야한다.

구개열로 태어난 아동 중 약 $50 \%$ 가 3 세경에 말 문제를 경험함에 도 불구하고(Chapman et al., 2008; Lohmander \& Persson, 2008; Willadsen, 2012), 지속적으로 말 문제를 보이는 아동을 미리 예측 할 수 있는 근거가 부족한 실정이다. Morris와 Ozanne (2003)은 2 세 전후의 구개열 아동을 3 세까지 종단 추적하여 음운과 언어능력 을 살펴보았다. 연구자들은 2세에 표준화된 검사도구에서 8-12개 월가량 표현언어능력이 지연된 구개열 아동과 표현언어능력에 지 연을 보이지 않은 구개열 아동이 3 세에 이르렀을 때 자발화에 나타 난 말.언어 수행력이 어떠한지 살펴보았다. 연구결과, 2 세에 표현언 어능력이 지연되었던 구개열 아동이 그렇지 않은 구개열 아동에 비 해 3세에 MLU가 유의하게 낮았으며 자음목록수가 유의하게 적었 고 파열음, 마찰음, 비음, 유음, 자음군을 포함한 모든 자음에서 유 의하게 낮은 자음정확도를 보였다. 또한 어중자음생략, 비음 선호, 비음 동화, 어말자음생략, 자음군생략 같은 음운변동 비율도 표현 언어가 지연되었던 구개열 아동이 그렇지 않은 구개열 아동에 비해 유의하게 높게 나타났다. 즉, 2 세경에 표현언어측면에서 지연을 보 였던 구개열 아동이 3 세에 이르러서도 여전히 지연된 언어 및 말소 리 발달 양상을 보인다고 보고하였으며 그 이유를 연인두폐쇄부 전, 인지 및 언어학적 문제, 동반된 음운 및 언어장애에 의한 것으로 보았다. 하지만 선행연구는 2 세경에 말.언어 발달 문제를 보이는 구 개열 아동을 집단으로만 비교하여 아동별 말.언어 수행력에 대한 개인차를 살펴보지 않았고, 표현언어능력 지연을 동반하지 않았던 구개열 아동이 실질적으로 일반 아동의 말.언어 발달 수준에 도달 하였는지 살펴보지 않았다. 그러므로 2세 이후 구개열 아동의 이후 시기 말.언어 발달을 또래 아동뿐만 아니라 표현언어지연 유무를 
바탕으로 예측할 수 있는 종단 관찰이 필요하다. 따라서 본 연구는 2세에 부모 보고에 의해 상이한 표현언어 수준을 보인 구개열 아동 을 추적 관찰하여, 3세에 이르렀을 때 자발화에 나타난 음운 및 언 어 발달 특성을 표현언어지연 유무에 따른 구개열 집단뿐 아니라 일반 아동과 비교해 살펴보고자 하였다. 또한 구개열 아동의 개인 별 수행력에 대해 자세히 알아보고자 한다.

\section{연구방법}

\section{대상자}

본 연구는 구개열 아동 13명(남 7명, 여 6명), 일반 아동 7명(남 3 명, 여 4명)을 대상으로 하였다. 구개열 아동은 대학병원 구개열 클 리닉에서 구개성형술을 받았으며(평균 수술월령 12.85 개월, 범위 11-18개월), 구개열 혹은 구순구개열 이외에 (1) 염색체 이상으로 인 한 증후군이 없다고 보고되었으며, (2) 뚜렷한 인지, 신경, 발달과 관 련된 의학적 소견 및 진단을 받지 않았고, (3) 신생아 청각선별검사 에서 검사 기준을 통과하였다고 보고되었으며, 24개월에 실시한 (4) 영아선별 교육진단검사(Developmental assessment for the early intervention program planning, DEP; Jang, Seo, \& Ha, 2008)에 서 의사소통 영역을 제외한 영역이 백분위 $35 \%$ ile 이상으로 정상 발달에 속하였다. 일반 아동은 양육자로부터 (1) 출생 및 발달상 문 제가 나타나지 않았다고 보고되었고, (2) 신생아 청각선별검사에서 검사 기준을 통과하였다고 보고되었으며, 24 개월에 실시한, (3) 영 아선별 교육진단검사(DEP)에서 모든 영역이 백분위 $35 \%$ ile 이상, (4) 한국판 맥아더-베이츠 의사소통발달 평가(Korean MacArthurBates Communicative Development Inventories, K M-B CDI; Pae \& Kwak, 2011)에서 표현어휘수가 연령 집단별 평균에서 $10 \% \mathrm{ile}$ 이 상, (5) 영유아 언어발달검사(Sequenced Language Scale for Infants, SELSI; Kim, Kim, Yoon, \& Kim, 2003)에서 수용 및 표현언어가 $10 \%$ ile 이상인 아동을 대상으로 하였다.

24 개월 평가 시 구개열 아동에게서 표현언어지연 동반 여부를 알 아보기 위해 영유아 언어발달검사(SELSI) 결과 중 표현언어능력을 기준으로 구개열 아동을 두 집단으로 나누었다. $-2 \mathrm{SD}$ 미만인 아동 7 명은 표현언어지연 구개열 아동, $-2 \mathrm{SD}$ 이상인 아동 6 명은 정상언 어발달 집단으로 구분하였다. 전체 대상자에게 24 개월에 실시한 영유아 언어발달검사(SELSI) 결과 및 구개열 아동의 구개열 유형은 Table 1에 제시하였다. 영유아 언어발달검사의 수용 및 표현언어 원 점수에 대한 집단 차를 살펴본 결과, 수용언어는 세 집단 간 유의한 차이가 나타나지 않았으며 $(H=4.033, d f=2, p=.133)$, 구개열 아동 중 한 명(DEL2)을 제외한 모든 아동의 수용언어 결과는 $10 \% \mathrm{ile}$ 이
Table 1. Participants' information

\begin{tabular}{lccc}
\hline & $\begin{array}{c}\text { DEL group } \\
(\mathrm{N}=7)\end{array}$ & $\begin{array}{c}\text { NLD group } \\
(\mathrm{n}=6)\end{array}$ & TD group (N=7) \\
\hline Gender (boy:girl) & $4: 3$ & $3: 3$ & $3: 4$ \\
Receptive language (\%ile) & $1-90$ & $20-85$ & $45-95$ \\
Expressive language (\%ile) & $<1-5$ & $15-60$ & $40-95$ \\
Cleft type & & & \\
SPO & 1 & 1 & \\
HSP & 2 & 3 & \\
UCLP & 2 & 1 & \\
BCLP & 2 & 1 & \\
\hline
\end{tabular}

$\mathrm{DEL}=$ delayed expressive language with cleft palate; $\mathrm{NLD}=$ normal language development with cleft palate; $\mathrm{TD}=$ typically developing children; $\mathrm{SPO}=$ soft palate only; $\mathrm{HSP}=$ hard and soft palate; UCLP= unilateral cleft lip and palate; $\mathrm{BCLP}=$ bilateral cleft lip and palate.

상이었다.표현언어는 세 집단간 유의한차이가나타났다 $(H=15.591$, $d f=2, p<.001)$. 사후 분석 결과, 일반 아동과 표현언어지연 구개열 아동에서 유의한 차이가 나타났으며 $(p<.001)$, 일반 아동과 정상언 어발달 구개열 아동은 유의한 차이가 나타나지 않았다( $p=.328)$. 대상자에 포함된 모든 구개열 아동은 24 개월에서 36 개월까지 추적 하는 동안 언어재활서비스를 비롯한 기타 재활서비스를 제공받지 않았다.

\section{자료 수집}

연구 절차는 한림대학교 생명윤리위원회의 승인(No. HIRB-2015065)을 받아 진행되었다. 대상자의 24 개월에 이루어진 영유아 언어 발달검사(SELSI) 및 36개월에 이루어진 자발화 수집은 언어병리학 전공 대학원생이 대상자의 가정에 방문하여 진행되었다. 자발화수 집은 총 40 분간 수집되었는데, 주양육자와 검사자가 각 20 여 분 동 안 아동들이 쉽게 접할 수 있는 장난감(주방놀이, 목욕놀이 등)을 이용해 아동과 상호작용하였다. 모든 상호작용 상황은 캠코더(Samsung HMX-H205BD)와 음성 녹음기(SONY ICD-PX333)를 통해 녹화 및 녹음되었다.

\section{자료 분석}

상호작용 자료는수집 후 2 주 이내에 영상 및 녹음 자료를 토대로 전사를 진행하였다. 전사는 아동의 목표 형태 및 음성 전사를 함께 기록하였다. 아동의 활발한 상호작용을 관찰하기 위해 상호작용 자료의 전반부 3 분과 후반부 2 분은 제외하였으며, 부모상호작용 15 분, 검사자 상호작용 15 분 자료가 전사되었다. 전사가 완료된 후 에는 제 1 저자가 녹음 자료를 다시 듣고 음성 전사의 정확성을 확인 하였으며 대상 아동들에게서 나타난 보상조음의 유형을 확인하고 
기입하였다.

전사 원칙은 Jung, Pae와 $\operatorname{Kim}$ (2006)을 참조하여 자료를 3번 반 복해서 들어도 전사가 불가능한 발성이나 발화는 전사하지 않았으 며, 모방과 자발화를 구분하지 않고 모두 전사하였다. 전사된 자료 중 감탄사나 간투사만으로 이루어진 발화 및 음절성 발성이나 자 곤처럼 의미가 분명하지 않은 발화는 분석에서 제외하였으며, 대답 하기 기능으로 산출한 '네, 응/어'는 첫 번째로 산출된 것만 발화로 포함시켰다.

모든 분석치는 아동이 산출한 발화 중 연속 50 개 발화를 선정하 여 분석하였다. 연속 50 개 발화는 전체 전사 자료에서 아동별 전체 발화수의 중앙값을 구하여, 중앙값 전후의 발화를 25개씩 택하는 방식으로 선정하였다.

\section{음운지표}

아동의 자발화에 나타난 음운능력 측정치는 평균음운길이(phonological mean length of utterance, PMLU), 단어단위 근접률(phonological word proximity, PWP), 단어단위 정확도(phonological word correction, $\mathrm{PWC}$ )와 같은 단어단위 음운지표와 자음정확도 (percentage of consonants correct, PCC) 및 자음목록(전체, 초성, 종성)을 분석하였다.

단어단위 음운지표의 분석 기준은 Yoon, Kim과 Kim (2013)을 참조하여 사용하였다. PMLU의 계산은 아동이 산출한 자음과 모 음에 1 점을 부여한 뒤 정조음한 자음과 이중모음에 1 점을 추가하 고 전체 점수를 합산한 뒤 발화수로 나누어 구하였다. 성인 발화를 기준으로 한 목표 형태와 비교하였을 때 아동이 추가한 음소나 음 절은 점수를 주지 않았다. 자음을 보상조음으로 대치한 경우 1점만 부여하였다.PWP는 (아동 발화의 PMLU)/(목표 형태 발화의 PMLU) 로 계산하였다. PWC는 (아동이 정확하게 산출한 어절수)/(전체 어 절수)로 산출하였다. PCC는 (정조음한 자음수)/(전체 산출된 자음 수) $\times 100$ 으로 계산하였다.

자음 목록은 Stoel-Gammon (1985)의 기준을 참고하여 서로 다 른 2 개 이상의 발화에서 산출된 자음만을 목록에 포함하였다. Hardin-Jones와 Chapman (2014)에 따라 구강 내 압력이 크지 않 은 /ㅎ/와 보상조음은 자음목록에 포함하지 않았다. 또한 자음 산 출 위치를 고려하여 전체 자음목록과 초성 및 종성 자음목록을 구 분하여 분석하였다.

\section{언어지표}

아동의 자발화에 나타난 언어능력 측정치는 서로 다른 낱말수 (number of different words, NDW)와 총 낱말수(number of total words, NTW), 평균낱말길이(mean length of utterance in words, $\mathrm{MLUw}$ ), 평균형태소길이(mean length of utterance in morphemes, MLUm)를 살펴보았다.

언어지표의 분석은 한국어 발화분석(Korean Language Analysis, http://kla.hallym.ac.kr/) 프로그램을 사용하였다. 코딩방법은 $\mathrm{Ha}, \mathrm{Seol}, \mathrm{So}$ 와 Pae (2016)와 동일하게 낱말 경계는 띄어쓰기로 구 분하고 문법형태소 경계는 '’로 구분하였으며 코딩 시 발화 내에 나 타난 단어 반복, 구 반복, 문장 반복은 모두 괄호 안에 넣어 낱말과 문법형태소 분석에서 제외하였다.

\section{신뢰도}

자료의 전사 신뢰도와 측정치의 분석 신뢰도를 위해 전체 자료 의 $15 \%$ 를 임의로 선정하여 전사자 간 신뢰도 및 분석자 간 신뢰도 를 구하였다. 전사자 간 신뢰도와 분석자 간 신뢰도는 제 1 저자와 언 어병리학전공 대학원생이 독립적으로 분석한 자료를 비교하였다. 전사 신뢰도는 (전사자 간 일치하게 전사한 자음수)/(제 1 저자의 전 사 자료 중 전체 자음수) $\times 100$ 으로 계산한 결과, $91.88 \%$ 였다. 음운 지표는 Cohen's Kappa를 이용하여 분석자 간 신뢰도를 측정하였 다. 음운지표 분석 결과, PMLU (.961), PWP (.958), PWC (.949), PCC (.912) 순으로 높은 분석자 간 신뢰도가 나타났다. 언어지표는 전사 자료의 문법형태소 경계를 나누는 코딩작업이 선행된 후, KLA 프로그램을 통해 자동으로 분석된다. 따라서, 언어지표의 신 뢰도는 문법형태소 경계의 코딩이 일관적으로 수행되었는지가 중 요하다. 문법형태소 경계에 대한 코딩 일치도는 (일치한 코딩 위치)/ (제 1 저자의 코딩 위치 $) \times 100$ 으로 산출하였다. 그 결과, 분석자 간 신뢰도는 $94.50 \%$ 로 나타났다.

\section{통계 분석}

통계 처리는 SPSS 22.0 프로그램을 사용하였다. 본 연구에 사용 된 데이터에 대해 정규성 검정을 한 결과, 정규분포가 나타나지 않 았으므로 측정치에 대한 세 집단 간 차이를 살펴보기 위해 Kruskal-Wallis H-test를 사용하였으며 유의 수준은 $p<.05$ 이다.

세 집단 간 유의한 차이가 나타난 경우, 사후 검정으로 MannWhitney U-test를 실시하였다. 사후 검정은 두 집단씩 짝지어 MannWhitney 검정을 3 회 실시하였으므로 사후 검정의 유의 수준이 a/ ${ }_{n} \mathrm{C}_{2}$ 로 수정(Bonferroni correction method)되었으며 $p<.05$ 로 조정 된 유의 수준(adjusted $p$-value)을 보고하였다. 기술통계 결과는 중 앙값과 범위를 사용하여 중심경향척도를 살펴보았다. 


\section{연구결과}

\section{음운 발달}

24 개월에 부모 보고에 의해 표현언어지연 집단과 정상언어발달 집단으로 구분된 구개열 아동과 일반 아동에게서 36 개월에 수집 된 50발화의 음운지표 분석결과를 Table 2에 제시하였다.

연속 50개 발화에서 각 지표의 중앙값을 살펴보면 PMLU, PWP, $\mathrm{PWC}, \mathrm{PCC}$ 는 집단 간 유의한 차이가 나타났다. 사후 분석 결과, PMLU (adjusted $p=.006$ ), PWP (adjusted $p=.015$ ), PCC (adjusted $p=.023)$ 모두 표현언어지연 구개열 아동이 일반 아동에 비해 유의 하게 낮았으며, 일반 아동과 정상언어발달 구개열 아동 간 유의한 차이는 나타나지 않았다. PWC는 사후 분석 결과, 전체 집단을 두 집단씩 짝지어 비교하였을 때 유의한 차이가 나타나지 않았다.

전체 자음목록수는 표현언어지연 구개열 아동이 7 개, 정상언어 발달 구개열 아동이 14 개, 일반 아동이 14 개였으며, 초성 자음목록 수는 표현언어지연 구개열 아동이 6 개, 일반 아동이 13 개로 나타났 으나 전체 자음, 초성 자음목록수에서 통계적으로 유의한 차이는 나타나지 않았다. 단, 종성 자음목록수는 일반 아동과 정상언어발 달 구개열 아동이 5 개, 표현언어지연 구개열 아동이 3 개로 표현언어 지연 집단이 유의하게 적었다. 사후 분석 결과, 정상언어발달 구개
열 아동과 표현언어지연 구개열 아동(adjusted $p=.003$ ), 일반 아동 집단과 표현언어지연 구개열 아동(adjusted $p=.012)$ 에서 유의한 차 이가 나타났다.

\section{언어 발달}

24 개월에 부모 보고에 의해 표현언어지연 집단과 정상언어발달 집단으로 구분된 구개열 아동과 일반 아동에게서 36 개월에 수집 된 50 발화의 언어지표 분석 결과를 Table 3에 제시하였다.

연속 50개 발화에서 각 지표의 중앙값을 살펴보면 NDW는 표현 언어지연 구개열 아동이 43 개, 정상언어발달 구개열 아동이 약 52 개, 일반 아동이 48 개였으며 집단 간 유의한 차이가 나타나지 않았 다. NTW는 표현언어지연 구개열 아동이 80개, 정상언어발달 구개 열 아동이 98 개, 일반 아동 94 개로 NTW 또한 집단 간 유의한 차이 가 나타나지 않았다.

$M L U w$ 는 표현언어지연 구개열 아동이 1.60 , 정상언어발달 구개 열 아동이 2.10 , 일반 아동 1.88 이었다. MLUm은 표현언어지연 구개 열 아동이 2.58 , 정상언어발달 구개열 아동이 3.46 , 일반 아동 2.84 로 나타났다. MLUw와 MLUm은 집단 간 통계적으로 유의한 차이 가 나타나지 않았다.

Table 2. Results of phonological measurement analysis

\begin{tabular}{|c|c|c|c|c|c|}
\hline & DEL group ( $N=7$ ) & NLD group ( $N=6)$ & TD group ( $\mathrm{N}=7$ ) & $H$ & $p$-value \\
\hline PMLU & $5.62(4.65-6.92)$ & $6.89(6.06-7.42)$ & $7.22(6.13-8.02)$ & 9.777 & .008 \\
\hline PWP & $.72(.64-.91)$ & $.91(.89-.93)$ & $.93(.87-.98)$ & 8.631 & .013 \\
\hline PWC & $.27(.16-.64)$ & $.63(.54-.67)$ & $.54(.47-.91)$ & 6.112 & .047 \\
\hline PCC & 38.41 (28.67-82.45) & $79.77(77.67-83.14)$ & $85.35(74.11-97.53)$ & 7.218 & .027 \\
\hline \multicolumn{6}{|c|}{ Number of consonants inventory } \\
\hline Total & $7(3-14)$ & $14(12-14)$ & $14(12-15)$ & 6.980 & .030 \\
\hline Initial & $6(1-13)$ & $13(11-13)$ & $13(11-14)$ & 6.196 & .045 \\
\hline Final & $3(1-4)$ & $5(4-6)$ & $5(4-6)$ & 12.940 & .002 \\
\hline
\end{tabular}

Values are presented as median (range).

$\mathrm{DEL}=$ delayed expressive language with cleft palate; $\mathrm{NLD}=$ normal language development with cleft palate; $T D=$ typically developing children; $P M L U=$ phonological mean length of utterance; PWP= phonological word proximity; PWC = phonological word correction; $\mathrm{PCC}=$ percentage of consonants correct.

Table 3. Results of language measurement analysis

\begin{tabular}{lccccc}
\hline & DEL group (N=7) & NLD group (N=6) & TD group (N=7) & $H$ & $p$-value \\
\hline NDW & $43.00(30-60)$ & $52.50(48-69)$ & $48.00(39-56)$ & 4.425 & .109 \\
NTW & $80.00(60-124)$ & $98.00(83-122)$ & $94.00(71-175)$ & 1.929 & .381 \\
MLUw & $1.60(1.20-2.42)$ & $2.10(1.66-2.44)$ & $1.88(1.32-3.50)$ & 2.98 & .225 \\
MLUm & $2.58(1.54-3.35)$ & $3.46(2.20-4.00)$ & $2.84(1.74-5.84)$ & 2.658 & .265 \\
\hline
\end{tabular}

Values are presented as median (range).

$D E L=$ delayed expressive language with cleft palate; $N L D=$ normal language development with cleft palate; $T D=$ typically developing children; NDW=number of different words; NTW= number of total words; MLUw= mean length of utterance in words; MLUm= mean length of utterance in morphemes. 


\section{구개열 집단의 아동별 말 · 언어 특성}

36 개월에 수집된 자발화를 토대로 일반적인 음운 및 언어지표뿐 만 아니라 보상조음 산출 여부를 구개열 아동별로 살펴보았다. 표 현언어지연 구개열 아동 7명 중 4명(DEL2, DEL3, DEL4, DEL7)에 게서 보상조음이 나타났으며, 정상언어발달 구개열 아동 6 명 중 1 명(NLD1)에게서 보상조음이 나타났다.

\section{음운지표}

대상자들의 36 개월 자발화에 나타난 모든 음운 측정치 값을 $\mathrm{Ta}-$ ble 4에 제시하였다. PMLU 값을 살펴보면 DEL1, DEL5 아동을 제 외한 5명의 표현언어지연 구개열 아동은 일반 아동 및 정상언어발 달 구개열 아동의 PMLU 범위의 최솟값보다 PMLU 값이 낮았다. 정상언어발달 구개열 아동 중 NLD2 아동은 PMLU가 6.06으로 일 반 아동의 PMLU 범위에 속하지 못하였으나 TD4 아동의 6.13과 큰 차이를 보이지는 않았다.

PWP 값을 살펴보면 DEL5, DEL6 아동을 제외한 5명의 표현언 어지연 구개열 아동은 일반 아동 및 정상언어발달 구개열 아동의 PWP 범위의 최솟값보다 PWP 값이 낮았다. 정상언어발달 구개열 아동은 모두 일반 아동의 PWP 범위에 속하였다.

PWC 값은 DEL5, DEL6 아동을 제외한 5명의 표현언어지연 구개 열 아동이 일반 아동 및 정상언어발달 구개열 아동의 PWC 범위의

Table 4. Results of phonological measures in all participants

\begin{tabular}{lcccccc}
\hline $\begin{array}{c}\text { Subject } \\
\text { no. }\end{array}$ & PMLU & PWP & PWC & PCC & \multicolumn{2}{c}{$\begin{array}{c}\text { Number of conso- } \\
\text { nant inventory }\end{array}$} \\
\hline DEL1 & 6.92 & .79 & .31 & 53.33 & 12 & 1 \\
DEL2 & 5.62 & .72 & .16 & 37.01 & 6 & 2 \\
DEL3 & 4.80 & .64 & .20 & 28.67 & 1 & 3 \\
DEL4 & 4.76 & .67 & .25 & 31.51 & 3 & 3 \\
DEL5 & 6.56 & .91 & .62 & 82.45 & 13 & 3 \\
DEL6 & 6.07 & .90 & .64 & 80.76 & 13 & 4 \\
DEL7 & 4.65 & .71 & .27 & 38.41 & 5 & 2 \\
NLD1 & 7.42 & .91 & .54 & 79.42 & 11 & 6 \\
NLD2 & 6.06 & .91 & .67 & 81.76 & 12 & 5 \\
NLD3 & 7.38 & .91 & .65 & 79.07 & 13 & 4 \\
NLD4 & 7.02 & .93 & .63 & 83.14 & 13 & 5 \\
NLD5 & 6.26 & .89 & .58 & 77.67 & 13 & 5 \\
NLD6 & 6.75 & .90 & .62 & 80.12 & 13 & 5 \\
TD range & $6.13-8.02$ & $.87-.98$ & $.47-.91$ & $74.11-97.53$ & $11-14$ & $4-6$ \\
\hline
\end{tabular}

$\mathrm{DEL}=$ delayed expressive language with cleft palate; $\mathrm{NLD}=$ normal language development with cleft palate; TD=typically developing children; $P M L U=$ phonological mean length of utterance; $\mathrm{PWP}=$ phonological word proximity; $\mathrm{PWC}=$ phonological word correction; $\mathrm{PCC}=$ percentage of consonants correct.
최솟값보다 낮았다. 정상언어발달 구개열 아동은 모두 일반 아동 의 PWC 범위에 속하였다.

PCC 값 또한 DEL5, DEL6 아동을 제외한 5명의 표현언어지연 구 개열 아동이 일반 아동 및 정상언어발달 구개열 아동의 PCC 범위 의 최솟값보다 낮았다. 정상언어발달 구개열 아동은 모두 일반 아 동의 PCC 범위에 속하였다.

초성 자음목록수를 살펴보면 DEL1, DEL5, DEL6 아동을 제외 한 4 명의 표현언어지연 구개열 아동이 일반 아동 및 정상언어발달 구개열 아동의 초성 자음목록수 범위의 최솟값보다 낮았다. 정상 언어발달 구개열 아동은 모두 일반 아동의 초성 자음목록수 범위 에 속하였다.

종성 자음목록수를 살펴보면 DEL6 아동을 제외한 6명의 표현 언어지연 구개열 아동이 일반 아동 및 정상언어발달 구개열 아동의 종성 자음목록수 범위의 최솟값보다 낮았다. 정상언어발달 구개 열 아동의 종성 자음목록수는 일반 아동의 종성 자음목록수 범위 와일치하였다.

모든 음운지표에 나타난 구개열 아동 개별 수행력을 종합해보면 24 개월에 부모 보고에 의해 표현언어지연을 보였던 구개열 아동 중 DEL5와 DEL6는 모든 음운지표에서 일반 아동의 말 발달 수준으 로 향상되었고, DEL1도 일부 음운지표에서 일반 아동의 수준에 도 달하여 점차 또래 수준으로 말 발달이 이루어지고 있음을 알 수 있 다. 반면 구개열 표현언어지연 집단 7명 중 4명(DEL2, DEL3, DEL4, DEL7)은 여전히 일반 아동에 비해 지연된 말 발달 수준을 보였다.

Table 5. Results of language measures in all participants

\begin{tabular}{lcccc}
\hline Subject no. & NDW & NTW & MLUw & MLUm \\
\hline DEL1 & 33 & 80 & 1.60 & 2.58 \\
DEL2 & 30 & 60 & 1.20 & 1.54 \\
DEL3 & 36 & 65 & 1.30 & 2.24 \\
DEL4 & 48 & 98 & 1.96 & 2.90 \\
DEL5 & 52 & 124 & 2.42 & 3.35 \\
DEL6 & 60 & 112 & 1.98 & 3.11 \\
DEL7 & 43 & 65 & 1.30 & 1.86 \\
NLD1 & 69 & 122 & 2.44 & 4.00 \\
NLD2 & 54 & 83 & 1.66 & 2.20 \\
NLD3 & 50 & 104 & 2.08 & 3.24 \\
NLD4 & 51 & 114 & 2.28 & 3.82 \\
NLD5 & 48 & 92 & 1.84 & 2.50 \\
NLD6 & 56 & 89 & 2.11 & 3.67 \\
TD range & $39-56$ & $71-175$ & $1.32-3.50$ & $1.74-5.84$ \\
\hline
\end{tabular}

$\mathrm{DEL}=$ delayed expressive language with cleft palate; $\mathrm{NLD}=$ normal language development with cleft palate; TD = typically developing children; NDW = number of different words; NTW= number of total words; $M L U w=$ mean length of utterance in words; MLUm= mean length of utterance in morphemes. 


\section{언어지표}

대상자들의 36 개월 자발화에 나타난 모든 언어 측정치 값을 $\mathrm{Ta}-$ ble 5에 제시하였다. NDW 개수를 보면 표현언어지연 구개열 아동 중 DEL1, DEL2, DEL3 아동이 일반 아동의 NDW 범위의 최솟값 보다 NDW 개수가 적었다. 정상언어발달 구개열 아동은 모두 일반 아동의 NDW 범위에 속하였다.

NTW 개수를 살펴보면 표현언어지연 구개열 아동 중 DEL2, DEL3, DEL7 아동은 일반 아동의 NTW 범위의 최솟값보다 NTW 개수가 적었다. 정상언어발달 구개열 아동은 모두 일반 아동의 NTW 범위 에 속하였다.

MLUw 값은 표현언어지연 구개열 아동 중 DEL2, DEL3, DEL7 아동이 일반 아동의 MLUw 범위의 최솟값보다 MLUw가 낮았다. 정상언어발달 구개열 아동은 모두 일반 아동의 MLUw 범위에 속 하였다.

MLUm 값은 표현언어지연 구개열 아동 중 DEL2 아동이 일반 아 동의 MLUm 범위의 최솟값보다 MLUm가 낮았다. 정상언어발달 구개열 아동은 모두 일반 아동의 MLUm 범위에 속하였다.

모든 언어지표에 나타난 구개열 아동 개별 수행력을 종합해보면 24 개월에 부모 보고에 의해 표현언어지연을 보였던 구개열 아동 중 DEL4, DEL5, DEL6은 모든 언어지표에서 일반 아동의 언어 발달 수준으로 향상되었고, DEL1, DEL7도 과반수 이상의 언어지표에 서 일반 아동의 언어 발달 수준에 도달하여 현재 또래 수준으로 언 어 발달이 이루어지고 있음을 알 수 있다. 반면 표현언어지연 구개 열 아동 7명 중 2 명(DEL2, DEL3)은 여전히 일반 아동에 비해 지연 된 언어 발달수준을 보였다.

\section{논의 및 결론}

본 연구는 24 개월에 부모 보고에 의해 표현언어가 지연된 구개열 아동과 표현언어에 지연이 없는 구개열 아동, 일반 아동을 추적하여 36 개월의 자발화 50 발화에 나타난음운 및 언어 특성을 살펴보았다.

음운 발달 측면 결과, PMLU, PWP, PCC 값은 24개월에 표현언 어가 지연되었던 구개열 아동이 일반 아동에 비해 유의하게 낮았으 며, 24 개월에 표현언어에서 지연을 보이지 않았던 구개열 아동은 36 개월에도 정상적인 말 발달을 보이는 것으로 나타났다. 자음목 록수를 보면, 초성 자음목록수와 전체 자음목록수에서는 통계적 으로 유의한 차이가 없었으나 표현언어가 지연되었던 구개열 아동 의 과반수 이상이 또래 아동의 자음목록수에 미치지 못하였다. 종 성 자음목록수는 표현언어가 지연되었던 구개열 아동이 일반 아동 은 물론 표현언어에 지연을 보이지 않았던 구개열 아동에 비해서도
유의하게 적었다. 음운 발달 측면의 결과는 2 세에 표현언어지연을 보였던 구개열 아동이 그렇지 않은 구개열 아동에 비해 자음정확도 가 낮고 자음목록이 적다고 보고한 Morris와 Ozzane (2003)의 연 구결과와 일치한다. 반면 24개월에 정상언어발달을 보였던 구개열 아동은 36 개월에도 일반 아동과 유사한 음운 발달 패턴을 보였다. 이는 초기 표현언어능력이 또래와 유사한 구개열 아동이 이후에도 지연되는 양상 없이 지속적으로 발달한다는 점을 나타낸다. 개별 아동에 따른 음운 측면 수행력을 살펴보면 24개월에 표현언어에서 지연을 보였던 구개열 아동 중 2 명만 12 개월 후 평가 시에 음운 측면 에서 또래 아동과 유사한 발달을 보였으며 1 명은 현재 음운 측면이 발달 중인 것으로 나타났다. 하지만 표현언어지연을 보였던 구개열 아동 중 과반수 이상은 음운능력에서 현저한 지연을 보인다는 점 을 알수 있다.

언어 발달 측면 결과, NDW, NTW, MLUw, MLUm으로 측정된 언어능력에서 집단 간 유의한 차이가 나타나지 않아 어휘와 구문 모두 구개열 아동과 일반 아동 간 차이가 없음을 알 수 있다. 이 점 은 24 개월에 지연된 표현언어능력을 보였던 구개열 아동에게서 중 재 없이 언어 측면이 일정 부분 또래 수준을 따라 잡았다는 것을 의 미한다. 이는 표현언어지연을 보였던 구개열 아동이 정상언어발달 을 보였던 구개열 아동에 비해 어휘 다양도는 유의한 차이가 없으 나 구문 측면에서 낮은 수행력을 보였다는 선행연구(Morris \& Ozzane, 2003)와 일부 유사한 결과이다. 하지만 개별 아동에 따른 언 어 측면 수행력을 살펴보면 24개월에 표현언어지연을 보였던 구개 열 아동이 집단 비교 시에는 일반 아동과 유의한 차이가 없는 어휘 및 구문 수행력이 나타났음에도 불구하고 일반 아동 중에서도 낮 은 수행력을 나타내는 아동과 유사한 수행력을 보였거나 일반 아 동 범위보다 결과값이 낮았다는 사실을 눈여겨보아야 한다. 이는 18 -30개월의 구개열 아동과 말 늦은 아동, 일반 아동의 말.언어 수 행력을 살펴본 연구결과와 유사하다( $\mathrm{Pi} \& \mathrm{Ha}, 2017) . \mathrm{Pi}$ 와 $\mathrm{Ha}$ (2017) 는 구개열 아동의 서로 다른 낱말수가 일반 아동보다는 유의하게 적지만 말 늦은 아동보다는 유의하게 많다고 보고하였는데 이를 통해 구개열 아동의 어휘 관련 언어능력이 표현언어능력이 상당하 게 지연된 아동에 비해서는 좋지만 또래 아동에 비해서는 지연되었 다는 것을 알 수 있다. 즉, 표현언어지연을 보였던 구개열 아동의 과 반수는 언어 측면에서 위험군에 속하며 지속적인 관찰이 필요하다.

본 연구에서는 구개열 아동의 집단 간 차이뿐 아니라 말.언어 수 행력의 개인차를 살펴보았다. 음운과 언어 발달 측면을 종합해보았 을 때 24 개월에 표현언어에서 지연을 보였던 구개열 아동은 음운 능력이 현저하게 지연되었을 뿐만 아니라 언어능력도 또래 구개열 아동이나 일반 아동에 비해 미흡한 수행력을 보였다는 점을 염두 
에 두어야 한다. 예를 들어, 24개월에 부모 보고로 실시한 언어평가 결과에서 수용언어와 표현언어 모두에서 $10 \%$ ile 미만이었던 DEL2 아동은 36 개월에도 여전히 말.언어 발달이 지연된 것으로 관찰되 었다. 따라서 추후 연구에서는 수용언어지연이 동반된 구개열 아동 이 36개월 이후 말.언어 발달에서 취약할 가능성이 높아지는지 살 펴볼 필요가 있다. 또한 24 개월에 언어 능력에서 지연을 보였던 구 개열 아동은 이후 시기에도 말.언어 발달 위험군에 속할 확률이 높 으므로 지속적으로 면밀한 관찰 및 평가가 요구되며 언어 측면보다 음운 측면에서 더욱 취약한 모습을 보이므로 음운 측면에 대한 조 기 중재가 강조된다는 점을 제안할 수 있다. 가령, 24 개월에 부모 보 고에 의한 언어발달검사를 실시했을 때 또래 아동에 비해 표현언어 측면에 지연을 보이는 구개열 아동에게 직접 중재가 어렵다면 음운 측면에 초점을 맞춘 부모 교육을 실시한다면 위험군 아동의 말소리 발달을 촉진하는 것에 도움이 될 것이다.

본 연구는 24개월에 표준화된 평가도구를 이용한 부모 보고에 의해 표현언어능력이 지연되었다고 확인된 구개열 아동 중 대다수 가 이후 시기에도 고위험군에 속한다는 점을 시사하였다. 즉, 지속 적으로 말.언어 문제를 동반할 가능성이 있는 구개열 아동을 선별 하는 기준을 제공한 것에 의의가 있다. 본 연구는 각 집단별 대상자 수가 적어 정규분포가 나타나지 않아 말, 언어지표의 비교에 제한 이 있을 수 있다. 향후 많은 수의 구개열 아동을 대상으로 지속적으 로 종단 연구를 실시하여 본 연구의 결과를 일반화할 수 있는지 살 펴보고, 구개열 아동을 정상언어발달 집단, 표현언어지연 집단, 표 현과 수용언어가 모두 지연된 전반적 언어발달지연 집단으로 구분 하여 말.언어 발달 과정을 면밀히 살펴볼 필요가 있다. 또한 24 개월 에 표현언어지연 집단으로 나뉘는 구개열 아동의 말.언어 발달에 영향을 미치는 요인이나 24 개월에는 표현언어지연으로 분류되었 으나 36개월에 자연적으로 일반적인 말.언어 발달 수준에 도달하 는 아동의 특성도 비교할 필요가 있다. 다시 말해, 일반적인 말.언 어 발달에 기여하는 요인을 아동의 의사소통태도, 정서 발달, 인지 수준, 중이염 유무, 부모의 양육방식과 태도, 상호작용 정도, 환경 언어의 질과 양 측면에서 다각적으로 살펴볼 필요가 있다. 그뿐만 아니라 36개월경 말.언어 수행력을 예측하고 설명할 수 있는 요인 이 24 개월보다 어린 시기에도 나타나는지 살펴볼 것을 제안한다.

\section{REFERENCES}

Broen, P. A., Devers, M. C., Doyle, S. S., Prouty, J. M., \& Moller, K. T. (1998). Acquisition of linguistic and cognitive skills by children with cleft palate. Journal of Speech, Language, and Hearing Research, 41, 676-687.
Chapman, K. L. (1991). Vocalizations of toddlers with cleft lip and palate. The Cleft Palate-Craniofacial Journal, 28, 172-178.

Chapman, K. L. (1993). Phonologic processes in children with cleft palate. The Cleft Palate-Craniofacial Journal, 30, 64-72.

Chapman, K. L. (2004). Is presurgery and early postsurgery performance related to speech and language outcomes at 3 years of age for children with cleft palate? Clinical Linguistics \& Phonetics, 18, 235-257.

Chapman, K. L. (2011). The relationship between early reading skills and speech and language performance in young children with cleft lip and palate. The Cleft Palate-Craniofacial Journal, 4, 301-311.

Chapman, K. L., \& Hardin, M. A. (1992). Phonetic and phonologic skills of two-year-olds with cleft palate. The Cleft Palate-Craniofacial Journal, 29, 435-443.

Chapman, K. L., Hardin-Jones, M. A., Goldstein, J. A., Halter, K. A., Havlik, R. J., \& Schulte, J. (2008). Timing of palatal surgery and speech outcome. The Cleft Palate-Craniofacial Journal, 45, 297-308.

Chapman, K. L., Hardin-Jones, M., \& Halter, K. A. (2003). The relationship between early speech and later speech and language performance for children with cleft lip and palate. Clinical Linguistics \& Phonetics, 17, 173-197.

Chapman, K. L., Hardin-Jones, M., Schulte, J., \& Halter, K. A. (2001). Vocal development of 9-month-old babies with cleft palate. Journal of Speech, Language, and Hearing Research, 44, 1268-1283.

Collett, B. R., Leroux, B., \& Speltz, M. L. (2010). Language and early reading among children with orofacial clefts. The Cleft Palate-Craniofacial Journal, 47, 284-292.

Grunwell, P., \& Russell, J. (1987). Vocalisations before and after cleft palate surgery: a pilot study. British Journal of Disorders of Communication, 22, $1-17$.

Ha, S. (2011). Parent-implemented early intervention for young children with cleft palate. Korean Journal of Communication \& Disorders, 16, 460-477.

Ha, S. (2014). Phonological characteristics of early vocabulary in young children with cleft palate. Phonetics and Speech Sciences, 6, 65-71.

Ha, S. (2018). Profiles of vocal development in Korean children with and without cleft palate. Clinical Linguistics \& Phonetics, 32, 46-69.

Ha, S., Seol, A., So, J., \& Pae, S. (2016). Speech and language development patterns of Korean two-year-old children from analysis of spontaneous utterances. Communication Sciences \& Disorders, 21, 47-59.

Hardin-Jones, M., \& Chapman, K. L. (2008). The impact of early intervention on speech and lexical development for toddlers with cleft palate: a retrospective look at outcome. Language, Speech, and Hearing Services in Schools, 
39, 89-96.

Hardin-Jones, M., \& Chapman, K. L. (2014). Early lexical characteristics of toddlers with cleft lip and palate. The Cleft Palate-Craniofacial Journal, 51, 622-631.

Hardin-Jones, M., Chapman, K., \& Scherer, N. J. (2006). Early intervention in children with cleft palate. The ASHA Leader, 11, 8-32.

Harding, A., \& Grunwell, P. (1996). Characteristics of cleft palate speech. International Journal of Language \& Communication Disorders, 31, 331-357.

Jang, H. S., Seo, S. J., \& Ha, J. Y. (2008). Developmental assessment for the early intervention program planning (DEP). Seoul: Hakjisa.

Jocelyn, L. J., Penko, M. A., \& Rode, H. L. (1996). Cognition, communication, and hearing in young children with cleft lip and palate and in control children: a longitudinal study. Pediatrics, 97, 529-534.

Jung, K. H., Pae, S., \& Kim, G. (2006). The early phonological development of Korean children. Korean Journal of Communication Disorders, 11, 1-15.

Kim, H., Kim, Y. T., \& Kim, S. (2002). Language development in cleft palate infants. Korean Journal of Speech Sciences, 9, 121-131.

Kim, M., \& Ha, S. (2013). Longitudinal study of early vocalization development in toddlers with and without cleft palate from 6 to 18 months of age. Communication Sciences \& Disorders, 18, 223-234.

Kim, Y. T., Kim, K. H., Yoon, H. R., \& Kim, H. S. (2003). Sequenced Language Scale for Infants (SELSI). Seoul: Special Education Publishing.

Kuehn, D. P., \& Moller, K. T. (2000). Speech and language issues in the cleft palate population: the state of the art. The Cleft Palate-Craniofacial Journal, 37, 1-35.

Lohmander-Agerskov, A., Söderpalm, E., Friede, H., Persson, E. C., \& Lilja, J. (1994). Pre-speech in children with cleft lip and palate or cleft palate only: phonetic analysis related to morphologic and functional factors. The Cleft Palate-Craniofacial Journal, 31, 271-279.

Lohmander, A., \& Persson, C. (2008). A longitudinal study of speech production in Swedish children with unilateral cleft lip and palate and two-stage palatal repair. The Cleft Palate-Craniofacial Journal, 45, 32-41.
Morris, H., \& Ozanne, A. (2003). Phonetic, phonological, and language skills of children with a cleft palate. The Cleft Palate-Craniofacial Journal, 40, 460470.

Pae, S., \& Kwak, K. C. (2011). Korean MacArthur-Bates Communicative Development Inventories (KM-B CDI). Seoul: Mindpress.

Park, B., \& Ha, S. (2016). Early vocalization and later phonological and expressive vocabulary development in children with and without cleft palate. Communication Sciences \& Disorders, 21, 355-370.

Peterson-Falzone, S. J., Trost-Cardamone, J. E., Karnell, M. P., \& Hardin-Jones, M. A. (2006). The clinician's guide to treating cleft palate speech. St. Louis, MO: Mosby.

Pi, M., \& Ha, S. (2017). Phonological characteristics of early vocabulary among children with cleft palate, late talking children, and typically developing children. Communication Sciences \& Disorders, 22, 328-340.

Scherer, N. J., \& D’Antonio, L. L. (1995). Parent questionnaire for screening early language development in children with cleft palate. The Cleft PalateCraniofacial Journal, 32, 7-13.

Stoel-Gammon, C. (1985). Phonetic inventories, 15-24 months: a longitudinal study. Journal of Speech, Language, and Hearing Research, 28, 505-512.

Willadsen, E. (2012). Influence of timing of hard palate repair in a two-stage procedure on early speech development in Danish children with cleft palate. The Cleft Palate-Craniofacial Journal, 49, 574-595.

Willadsen, E., \& Albrechtsen, H. (2006). Phonetic description of babbling in Danish toddlers born with and without unilateral cleft lip and palate. The Cleft Palate-Craniofacial Journal, 43, 189-200.

Yoon, M. S., Kim, J. M., \& Kim, S. J. (2013). Phonological whole-word measures of spontaneous speech in children two to four years of age. Journal of Speech \& Hearing Disorders, 22, 69-85.

Young, S. E., Purcell, A. A., \& Ballard, K. J. (2010). Expressive language skills in Chinese Singaporean preschoolers with nonsyndromic cleft lip and/or palate. International Journal of Pediatric Otorhinolaryngology, 74, 456-464. 


\section{국문초록}

\section{구개열 아동의 초기 표현언어지연 동반 여부에 따른 음운 및 언어 발달}

피민경 $\cdot$ 하승희 ${ }^{2}$

1한림대학교 대학원 언어병리청각학과, ${ }^{2}$ 한림대학교 언어청각학부 및 한림청각언어연구센터

배경 및 목적: 본 연구는 24 개월에 부모 보고에 의해 상이한 표현언어수준을 보인 구개열 아동을 추적 관찰하여, 36 개월에 이르렀을 때 자발화에 나타난 음운 및 언어 발달 특성을 살펴보고자 하였다. 방법: 24 개월에 표현언어가 지연된 구개열 아동 7 명을 표현언어지연 구 개열 아동, 표현언어가 정상인 구개열 아동 6 명을 정상언어발달 구개열 아동으로 구분하였으며, 비교 집단으로 일반 아동 7 명을 포함해 총 20 명의 아동을 대상으로 하였다. 대상자들이 36 개월에 이르렀을 때 세 집단의 자발화 50 발화에 나타난 음운 및 언어 발달 양상을 살 펴보았다. 결과: 표현언어지연 구개열 아동은 일반 아동에 비해 모든 음운지표 결과가 유의하게 낮았으며, 정상언어발달 구개열 아동과 일반 아동은 유의한 차이가 나타나지 않았다. 모든 언어지표는 세 집단 간 유의한 차이가 나타나지 않았으나 표현언어능력이 지연된 구 개열 아동 중 절반은 일반 아동의 언어 발달 수준에 미치지 못하였다. 논의 및 결론: 본 연구는 초기에 표현언어능력이 지연된 구개열 아동이 이후 평균음운길이, 단어단위 근접률, 단어단위 정확도, 자음정확도, 자음목록 면에서 일반 아동은 물론 표현언어능력이 정상 범주였던 구개열 아동에 비해서도 취약하다는 점을 보여주었다. 따라서 본 연구결과는 2 세에 부모 보고를 통해 말.언어 발달 위험군으 로 선별된 구개열 아동에게 음운 측면에 초점을 맞춘 조기 중재를 시작하는 것이 적절하다는 점을 시사한다.

핵심어: 구개열, 표현언어지연, 음운 발달, 언어 발달, 조기 중재

본 논문은 한림대학교 교비연구비(HRF-201804-010)에 의하여 수행되었음.

\section{참고문헌}

김민영, 하승희(2013). 6-18개월 구개열 영유아와 일반 영유아의 발성 발달에 관한 종단연구. 언어청각장애연구, 18, 223-234.

김영태, 김경희, 윤혜련, 김화수(2003). 영유아 언어발달 검사(SELSI). 서울: 도서출판 특수교유.․

김효선, 김영태, 김석화(2002). 구개파열 영유아의 언어발달 특성 연구. 음성과학, 9, 121-131.

박보라, 하승희(2016). 구개열, 일반 영유아의 초기 발성 및 음운, 표현어휘 발달 비교. 언어청각장애연구, 21, 355-370.

배소영, 곽금주(2011). 한국판 맥아더-베이츠 의사소통발달평가(K M-B CDI). 서울: 마인드프레스.

윤미선, 김정미, 김수진(2013). 자발화 문맥에서의 단어단위음운 평가. 언어치료연구, 22, 69-85.

장혜성, 서소정, 하지영(2008). 영아선별 교육진단검사(DEP). 서울: 학지사.

정경희, 배소영, 김기숙(2006). $12,18,24$ 개월 영유아의 음운발달 특성. 언어청각장애연구, 11, 1-15.

피민경, 하승희(2017). 구개열 아동, 말 늦은 아동, 일반 아동의 초기 어휘에 나타난음운 특성. 언어청각장애연구, 22, 328-340.

하승희(2011). 구개열 영유아를 위한 부모 중심 조기언어중재가 말-언어발달에 미치는 효과. 언어청각장애연구, 16, 460-477.

하승희(2014). 구개열 아동의 초기 어휘에 나타난음운 특성 연구. 말소리와음성과학, 6, 65-71.

하승희, 설아영, 소정민, 배소영(2016). 자발화 분석을 통한 만 2세 한국아동의 말-언어발달 특성. 언어청각장애연구, 21, 47-59. 